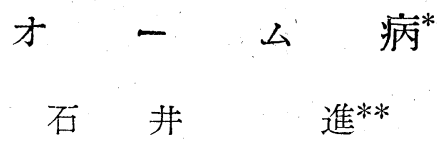

オーム病は元来オーム類の一つの伝染病であり, 人体 ヘの感染は主として鳥からくる場合が多い. ヨーロッ パ,アメリカなどに执いては毎年人の感染が報告されて いる.日本では, この病気についての研究が今日まで浪 とんどなされていなかった。たまたま 1952 年大森並び に著者ら, 同時に斎藤 (保) らによって山羊の肺炎例か ら, 次いで特からオーム病群ウイルスの分離が日本では じめて成功するに括よんで, 医学関係者の間にも深い興 味がもたれ, 研究がはじめられたというのが実情である. 最近新聞, 雑誌などにオーム病の人体感染例が報告され, 大分人心に恐怖を与学ているようであるが，人のオーム 病はすでに戦前から日本に存在していたものであり,た だ気がつかずに今日にいたったものと思われる。

本年 (1957年) 2 月 8 日このオーム病に関するシンポ ジウムが, 日本ウイルス学会東日本支部会主催のもと に, 農林省家畜衛生試験場に括いて開催された. この機 会にあたって，日獣会誌編集委員会のこわるるままに， このシンポジウムの概要をごく平易に書き経り, 読者各 位の参考に供したいと思う。ちなみに同シンポジウムの 講演題目を参考までに記載して置く.

(1)戦後日本に打けるオーム病の概要(石井進・家衛試) (2)家畜のォーム病について（大森常良・家衛試）(3)鳥類 のオーム病について (川島秀雄・動医検) (4)オーム病ウ イルスの性状（松本稔・伝研）(5)オーム病の病理（石谷 類造・家葦試) (6)オーム病ウイルスの超薄切片による電 子顕微鏡的研究（田島正典・日生研）(7)山羊のオーム病 の免疫試験(斎藤保二・北研) (8)オ一么病の治療試験 (石 井進・家衛試) (9)オーム病患者の発生例について(徐ら・ 関東聥信病院）(10) 自験例から見たオーム病の臨床（北 本治 - 伝研病院) (11) 原発性異型肺炎々の他の疾患に 牤けるミヤガワネラ(オーム病ウイルス) 抗体(後藤敏 夫・相模原病院) (12) 人並びにオーム病ウイルス（R. O. AnsLow. 米軍406総合医学研究所).

\title{
病気と症状
}

現在までに日本でオーム病の発生が認定された動物 は, 山羊, 牛, 緬羊, 人, オーム, セキセイインコ, コ キンチョウ, オカメインコ, ジウシマツ, 文鳥, 沜であ る.

*ここでいうオーム病とは, 人の第四性病を除く psittacosis-lymphogranuloma venereum group viruses による人, 小鳥, 哺乳動物の病気を仮称し たものである.

** 農林省家畜衛生試験場

日獣会誌 10 (1957) 
り, 違和, 食欲中絶, 解熱飞平行して沈縟, 水様鼻汁, 消衰, 眼嵗, 筋肉のスパスム, 麻痺, ついに起立不能と なる.ときには失明, 痤攣性発作, 旋回運動, 体並びに 四肢の完全麻痺, 起立不能, 擎死という急性経過をとる ものもある。

緬羊：すでに McEWen, STAMP \& LITTLE Johr(1951) は, 英国に和いて, 緬羊の地方性流産の病原としてオ一 ム病群ウイルスを分離している. また米国でも, これに 一致する緬羊の病例が認められているので, 日本に执い ても, 緬羊にこれに一致する病例の存在が予想されてい た、たまたま1956年川上は北海道で緬羊の翼からオーム 病群ウイルスを分離することに成功した。しかしその病 羊と流産との関係は不明で, 果して流産に関係があるも のか, 山羊ウイルスをた牛ウイルスによる緬羊の感染例 であるか, 今後の研究に待たねばならない。

猫：BARER（1944）性子猫の肺炎病巣からオーム病群 ウイルスを検出している. 日本ではまだ猫からは発見さ れていない。しかし当然日本の猫にもオーム病群ウイル スによる肺炎があるであろうことが予想される。

\section{b. 人}

徐ら (関東遁信病院) の報告に上ると, 東京都大田区 の一家族が 5 名 (1956年) 相継いで感冒様疾患にかかっ たが，X線により，肺に一過性陰影のあることが認めら れた.オーム病群ウイルスによる補体結合反応を行った ところ, そのうちの 3 名が陽性であった. 同家庭ではセ キセイインコ, ジウシマツを飼っているが, これらがし ばしば死ねといらことをきいたので, 生存している小鳥 の血清を検査したところ, オーム病ウイルスに対する抗 体が証明された。患者から病原を分離すること悢成功 しなかったが, 上述の理由から, これをオーム病汭か った人体例と推定した，患者は残らずテトラサイクリン 系抗生物質で治瘾している. 次いで同年さらに品川区の 小鳥愛好家庭に括ける 3 例の発生例を举げている. 症状

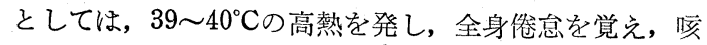
嗽, 喀痰が著しく, 高熱は $5 \sim 10$ 日つづく. 患者血清中 には, 病日の進行とともに, オーム病抗体が上䄯した。

北本 (伝研病院) は, 血清反応上オーム病患者之推定 された1例を挙げている．53才の主婦で小鳥を愛好して いた. ある朝起床したが, 目まいがして発熱, その後 2 $\sim 3$ 日の間悪感戦慄, 目末い, 頭痛, 悪心, 嘔叶がつび いた. 入院当時の主訴は, 前額部のひどい頭痛, 高熱, 咳嗽であり, X線検查の結果, 左側中肺野から下肺野に いたる広範囲な肺炎性の陰影が認められた。クロール・ テトラサイクリンの速日経口投与を行った結果, 下熱し た。

後藤は相模原病院の入院並びに外来患者の原発性異型 肺炎, その他いろいろな疾患について, 血清のォーム病 ウイルスに対する補体結合反応, 並びに少数の患者の血
清について血球凝集阻止反応を行った。 その結果, 多数 の患者に陽性反応を呈するものを認めた。

アンスロー（米軍 406 医学総合研究所）は，自身が日 本に技いてオーム病にかかった自覚症状を述べた．同氏 は病原の分離は行わなかったが, 確実に抗体の上昇を認 め, オーム病と判定した. 症状として発熱, 悪寒, 戦 慄, 関節痛を覚觉, とくに強烈な頭痛が伴った. 同氏は これを契機として, 東京在住の小鳥眅売業者約 100 名の 血清について補体結合反応を行い，きわめて高率に陽性 反応を認めた。

\section{c. 小鳥}

川島ら (1954年) は, 兵庫県下に和いて, 白文鳥, ジ ウシマツからオーム病ウイルスをはじめて分離し, 次い でアンスロー (1955年) もまた東京都内の小鳥屋から得 たセキセイインコ, ジウシマツ, 文鳥から, 同様ウイル 不分離した. 大森ら $(1955,56,57$ 年) も東京に执い て, オーム, インコ, コキンチョウ, ジウシマツ, 交 鳥, さらに鳩加同様オーム病ウイルスを検出した.

小鳥の感染症状は急激で, 敗血症のもとに多くが死 ぬ. 外観的飞初期動作の弛緩, 被毛の这立, 口嘴周囲 の貧血, 下劁をきたす。解剖では肝と脾の腫脹が著し く, 肝・脾から, マウスの腹腔内注射によって容易にウ イルスを分離することができる.

以上の記載から, わが国机けるオーム病は, 山羊, 緬羊, 牛, 小鳥とくにオーム, セキセイインコ, コキン チョウ, オカメインコ, 文鳥, ジウシマツ, 沜などに発 見されていることがわかる. しかし今後これ以外の動物 や小鳥化発見されるであろ弓，そして山羊, 緬羊, 4 および人では肺炎が主徴であり,な叔牛では脳膜脳炎を 起すこともある。これまた将来他の哺乳動物に脳膜脳炎 を起すものが発見されるかも知れない，これに反し，小 鳥では病性急激で, 肺炎が発生する以前に敗血症を起す ものである. この場合, 常に肝・脾の腫脹が著しい.

異なる宿主相関の感染性

動物種を異にして検出される病原は, いわゆるプシッ タコーシス・リンホグラニュローマ・ベネレウム群ウイ ルス（以下P L V 群ウイルスと略称）に属するので, 動 物種を異にしたものに相互感染があるか, はなはだ重要 な問題と思われる. 小鳥由来のウイルスが人オーム病の 病原となることは，すで汇認定された事実である。乙か し牛オーム病ウイルスが緬羊または山羊オーム病の病原 そなるか, あるいはこれら哺乳動物由来のウイルスが小 鳥オーム病の感染原となるか, 反対に小鳥ウイルスが烳 乳動物に自然感染するか, また哺乳動物由来のウイルス が人に自然感染するかは，今後なさるべき重要な研究問 題である.しかしこの問題に対し一指針となる各々動物 種を異にした個体から検出されたウイルスの同定試監 
は, 現在血清学的分野では信頼度が低い，ただわずかに 数株のウイルスに対して動物試験その他によって若干ウ イルス株の異同が推定されている現状に過ぎない.この ことは後述ウイルスの項汇域っ.

現在の知識では, 動物種を異にする場合の相関自然感 染は，小鳥と人との場合が一番強いと考兄られる．この ことは, 日本に特ける現在までの人体感染例の診断が, いずれも病原の証明ではなく,オーム病群ウイルスに対 する抗体の証明と臨床症状，X線照射，テトラサイクリ ン系抗生物質に対する治病効果から行われ，患者と小鳥 とのつながりがとくに重視され，判定の条件としてとり 票げられていることでる明らかである（諸外国の文献を 見ても同様). しかし日本に抢ける今後のオーム病の人 体感染例に执いては，ぜひとも病原ウイルスの分離が行 われるように望んでやまない。

ただし人体感染例では, 山羊, 牛, 緬羊, 小鳥などの 場合と異なり，糞から容易にウイルスが証明されないの で, 病原分離に困難性がともなららしい，その他の異種 動物間の自然感染はあって子少ないるのであろう。

\section{病原ウイルス}

大きさ並びに形態からは，宿主を異にして検出された ウイルスの区別は不可能近い。一般に小鳥由来のウイ ルスは，哺乳動物由来のものよりも小さいといわれてい るが，判別は無理である. P L V 群ウイルスの大きさは :300 400 m $\mu$ で, 電子顕微鏡像では球型を呈している. いずれのウイルスるふ化鷄卵の卵黄囊内でよく増殖し, 組織培養でも同様よく発育する，現在のところ，これら 動物種を異にして検出されるウイルスの分類, 同定は, 血清学的の方法では全く不可能であって, これは類属反 㐫強く, 各ウイルスが共通抗元をもっているからである.

現在動物種を異にして㭘出されたウイルスの性状の差 違として知られていることは，山羊や牛から分類された ものは, モルモットに病原性が強く, 病原をその腹腔内比 接種すると，線維素性腹膜炎を容易に起して感染する。 マウスに対しては感染性が強くない，これとは全く反対 飞, 人や小鳥から分離されたものは，モルモットには病 原性が弱く（ただし人から分離された Borg. Louisiana 株だけはこの例外で，強いといわれている），マウスに

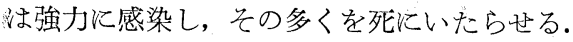

な执山羊由来のウイルスは, 牛由来のむのよりる一層 モルモットに病原性が強い.

また䲴から分離されたものは，他の小鳥から分離され たものと若干性状が異なる。すなわちウイルスを沜の脳 内接種すると，1週間前後で神経症状を起して擎死 し, 各臟器および賴からウイルスを証明するが, 鳩以外 の小鳥に由来するウイルスでは, 鳩は死なず, 他の臓器 紀拈けるウイルスの証明もほとんぞできない。しかしマ
ウスに接種した場合は, 両者の区別は洼とんどなく、一 様にマウスを致死せしめる．ただし一部に腹腔内注射の 場合, 鳩由来のものは, 他の小鳥由来のものより病原性 が弱いと述べている人もある.

宿主細胞内侵入して基本小体を形成するまでのオー ム病ウイルス粒子の增殖過程の変化を，マウスおよびふ 化鶏卵で電子顕微鏡を用いて観察した田島 (日生研)の 業績には興味がもたれた. 使用したウイルスは, 牛由来 脳膜肺炎ウイルス，沜由来扔よびインコ由来のものであ ったが, 牛由来と鳥由来のものとの間に, 発育過程に拉 けるウイルス粒子の変化様相の確たる差違を観察するま でにはいたっていない.

\section{治療と予防}

このウイルス群による病気には，テトラサイクリン系 抗生物質 (アクロマイシン, オーレオマイシン, テラマ イシンなど)が特效的治病効果を持つことは, 人体感染 例化拮いて証明されている。

テトラサイクリン系抗生物質は, 山羊のオーム病の治

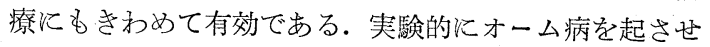
た山羊に, 発熱期汇連日アクロマイシンを11日間投薬し た後, 発病第14日目に殺して病理組織的に肺炎の所見を 観察したところ, 対照の無治療群にはひどい肺炎病巣が 低然存在していたにもかかわらず，治療群には肺炎病変 が認められなかった。また治療群では，肺をはじめ各臟 器からウイルスが全く証明されなかった。 このことは, アクロマイシンがこの種の肺炎にいかに卓效があるかの 実証を示す歹のと思 5 。

牛の肺炎について行った治療でも, 同様の結果が得ら れている. この際, 同時消化器内および䔬中のウイル スも全く陰性に転化している. しかしオーム病群ウイル スによって起る牛の脳炎の治療には, テトラサイクリン 系抗生物質はまだ試反られていないが，発病初期のもの ではある程度の效果があるものと思われる。

小鳥のオーム病を人工的泎ることはむずかしい，鴻 以外で性, 多く敗血症を起し, 急性経過で死几でしま う。辛うじて作り得たジウシマツの人工感染例では，テ クロマイシンの治病效果が認められている.

予防に関しては，方化鶏卵培養生ウイルス，クリスタ ルバイオレット・ワクチン, 紫外線照射不活化ワクチン による免疫試験がモルモット，山羊で行われた，免疫の 方法としては，皮下注射，気道内注入なぞが試みられた が, その結果, 紫外線不活化ワクチンの気道内注入があ る程度, あと感染汶対して效果があることが認められて いる.ただし気道内注入は, 免疫法としては若干動物体 漳害を与兄る危険性が考兄られる。またリケッチア・ ワクチンに用いられる $30 \%$ 䓞糖液で感染マウス肺病変の 乳剤を作り,これをエーテル・エタノール液または重ク

日獣会誌 10 (1957) 
ロム酸で処置したワクチンは，マウスの鼻腔内免疫実験 でさらに良好な免疫效果が認められたという。

これらの実験は，あと感染注対して完全肺炎を防止 したのではなく，対照群に比べて肺炎が軽く，また小範 囲に止まるという程度のもので, 今後さらになすべき研 究が数多く残されている. しかしオーム病に対しては, テトラサイグリン系抗生物質があまりにも特効的仁作用 するので，防疫上からい党ば，むしろ早期汇発見し，た だちに治療した汪らが確信がもてるよ5に思われる。た だし家畜や小鳥の場合には，これらの薬品が比較的高価 につく点は残念である.

\section{むすび}

P L V 群ウイルスのうち, 人の第四性病ウイルスにつ いては,すでにわが国に㨟いて，宮川博士を中心にし て, 赫々たる研究業績があげられているが, オーム病に ついては, つい数年前まで,わが国では医学界と獣医学 界とを問わず，ほとんど研究がなされていなかった。た またま大森和よび著者ら(1952年), 同時斉藤らによっ て, 山羊の肺炎病巣からこのウイルス群のあるメンバー が検出されるに拉よんで, オーム病の研究は急に盛んと なり，哺乳動物から小鳥燋んで，1956年には人体感染 も認定されるにいたった。

ただとくにこの際，強調したいことは，現在までの人 体感染例は, いずれも臨床症状, 抗体の証明, 感染患者々 小鳥飼充との関係などから判定されたもので，病原たる オーム病ウイルスを確実に分離したものは 1 例もない。 これらの人体感染注間違いないと思われるが，今後は ぜひ人体からも病原ウイルスを分離するよう希望して やまない。

これに対し, 牛, 山羊, 緬羊执よび各種小鳥のオーム 病例では, いずれも病原たるオーム病群ウイルスが分離 され，人工感染によって自然感染と同様の肺炎が形成さ れることが判明している．また小鳥では敗血症を起し， 自然感染之同様, 脾腫と肝腫大が見られている.

感染については次のことが知られる. 牛, 山羊, 緬羊 などの同種間では, 覜によって污染された飼料その他の 採食による消化器感染か, 同様污染された塺埃の吸入に よる気道感染が主体と考兄られる、動物種を異にした場 合の相関感染沉ついては，はっきりしていない。またこ れらの哺乳動物のオーム病が，はたして人体に自然感染 するかは明らかでない。

小鳥同種間では, 病鳥の糞を介しての感染が主体で, 直接病鳥との接触泡洙感染も一部考兄られる。な物鳩か ら検出されたりイルスは, 沜以外の小鳥から分離された ものとは若干性状が異る。

人体では, 病鳥からの感染が主体で, 患者から健康人 への感染は必ずしも多くはないようである.な捻患者の
粪には, 病畜や病鳥の場合とちがい, ウイルスは排泄さ れないらしい。

山羊や牛のオーム病に捻いて, 臨床的には肺炎の症状 を全く認めないものからオーム病群ウイルスが糞に証明， される実例があり，また翼にウイルスが証明されるにも かかわらず，血中抗体を全く認めないものもある。 1953 55年酒畜衛生試験場で行った山羊就よび牛の才 一ム病に関する疫学調査によると, 千数百頭の山羊の血 清中の抗体証明の成績は $44 \%$ の陽性，牛血清では $35 \% の$ 陽性となっている. 以上の事柄は，山羊や牛などの動物 側と, このウイルス感染との相関関係の複雑性を示すむ ので, 従ってこのウイルスによる病気の防圧が, 将来関: 係者の頭痛のた㸚となりはしまいかと拈それられる。

わが国の小鳥のうち, セキセイインコ, 交鳥, ジウシ マツ, コキンチョウ, オカメインコ, オーム, 鳩などに オーム病の感染がある。これらが人体感染の根元をなす といら予測のもとに, 小鳥飞路忷るオーム病の根絶が望 まれる，このためには死鳥の衛生的措置，篭の消毒など が必要である.これと同時に，小鳥のオーム病にテトラ サイクリン系抗生物質が卓效があることから，日常飲料 水にこれを混ぜて与え，感染を未然に防ぐことが望まれ。 る.

\section{アメリカ太平洋岸の人のオーム病}

オーム病はシッタコーシスと乎ばれるが, これはオー ムに発生する病気の意味であるから一般に鳥に発生した この種の病気には, 鳥といら意味を含んだオーニソーシ スという名称を使うことが,一部に提唱されている。米 国太平洋岸のオレゴン州に起こった人体感染例を岕げて みよ5.この病気の流行した七面鳥の飼養場で, 13 人の 従業員中 3 人が感染し, 5 占 1 人は1956年 2 月に死亡し た.防腐の処置をすませた死体なので特種検査はできな かったが，病巣はよく認められた。別の飼養場では，使 用人 9 名中 3 名が感染し, 補体結合反応で 1 名は陽性, 他は疑似であった。これら 2 つ飼養場の死んだ七面鳥 を処理した化製場には，38名の従業員がいたが，5名が 確実, 21 名が疑似という実に70\%の罹患率を示した。健 康な七面鳥を買って自家で解体調理したある家では, 重 度の肺炎感染によって主人が死亡し, 病原体が分離さ れ，またその妻はさいわいに死をを妨れたが，陽性の 補体結合価を示し, さらにその家の使用人は, 病気にか かっている間に 1：2から 1 ：32へと価が上年した。

これらの近所にある第 3 の飼養場から出された外観上 健康な七面鳥を取り报った解体処理場では，同年 5 月に 102 名の従業員中 19 名がオーニンーシスの症状をあらわ し, 5 ち 7 名が補体結合陽性であった。この地域で䍙患 した86名（5ち2 名は死亡）を調べると，5名が七面鳥 飼盖場の使用人, 52 名が鵎の解体処理人, 29 名が同じ化 製場にはたらく従業員であった。以上の5ち28名は入院 する必要があり，あるものは入院数週間に及んでいる。 平均の経過は 17.8 日間であった。これらの人々は直接七 面鳥に接触したことのないのが大部分であるから，主と して空気感染によったものと推定された。(J.A.V.M. A., 130, 118, 1957) SS 